\title{
Traditional uses, phytochemistry and biological activities of Cotula cinerea Del: A review
}

\author{
Mebarki Lakhdar ${ }^{1,2 \star}$ \\ ${ }^{1}$ Laboratory of Valorization of Vegetal Resource and Food Security in Semi-arid Areas, Southwest of Algeria, ${ }^{2}$ Department of \\ Biology, Faculty of Natural Sciences, Tahri Mohamed University, BP417, Bechar. Algeria
}

*For correspondence: Email: mebarki76@yahoo.fr; Tel: +213663890531

Sent for review: 4 August 2017

Revised accepted: 15 January 2018

\begin{abstract}
Cotula cinerea Del. belongs to the family Asteraceae. It is widely used in the traditional medicinal system for the treatment of various ailments such as colic, cough, diarrhea, digestive disorders, rheumatism, urinary and pulmonary infections, fever and headaches. Cotula cinerea contains a wide range of phytochemical compounds such as saponins, essential oils, tannins, flavonoids, steroids, and terpenoids. This paper reviews information pertaining its traditional uses, phytochemistry and biological activities such as antibacterial, antifungal, antioxidant, herbicidal, anti-diarrheal and analgesic properties. It is hoped that the information presented here might stimulate further studies that will possibly lead to development of therapeutic agents from this plant.
\end{abstract}

Keywords: Asteraceae, Cotula cinerea, Traditional uses, Phytochemistry, Biological activities

\begin{abstract}
This is an Open Access article that uses a funding model which does not charge readers or their institutions for access and distributed under the terms of the Creative Commons Attribution License (http://creativecommons.org/licenses/by/4.0) and the Budapest Open Access Initiative (http://www.budapestopenaccessinitiative.org/read), which permit unrestricted use, distribution, and reproduction in any medium, provided the original work is properly credited.

Tropical Journal of Pharmaceutical Research is indexed by Science Citation Index (SciSearch), Scopus, International Pharmaceutical Abstract, Chemical Abstracts, Embase, Index Copernicus, EBSCO, African Index Medicus, JournalSeek, Journal Citation Reports/Science Edition, Directory of Open Access Journals (DOAJ), African Journal Online, Bioline International, Open-J-Gate and Pharmacy Abstracts
\end{abstract}

\section{INTRODUCTION}

Herbs are largely used in ethnomedicine in the form of traditional preparations or derivatives of their pure active ingredients [1]. Medicinal plants represent natural sources of agents that can be used for the treatment of several diseases [2]. According to the World Health Organization (WHO), a large percentage of the people in developing countries depends mostly on medicinal plants for basic healthcare needs [3]. Medicinal plants have played a central role in the drug discovery process, due to their richness in bioactive natural products [4]. Indeed, several classes of bioactive compounds such as saponins, phenolics, lignans, glycosides, flavonoids, terpenes, and alkaloids have been used in the modern drug system, due to their potent therapeutic properties $[5,6]$.

However, some information on plants used in traditional medicine are not readily available to the scientific community because they are presented in the language of the local population, and so are limited in circulation to those localities [7]. Many researchers have discussed the possibility of integrating traditional medicine into the public health system [8]. This requires collection, organization and wide publication of all information about traditional medicine.

Cotula cinerea is one of the most used plants in traditional medicine in the northern Sahara of 
Algeria and in Morocco. The present review highlights the phytochemistry, and the various traditional uses and pharmacological properties of $C$. cinerea.

\section{CLASSIFICATION OF C. CINEREA}

The classification and vernacular names of $C$. cinerea are given in Table 1.

Table 1: Classification of $C$. cinerea

\begin{tabular}{lll}
\hline Kingdom & Plantae & Reference \\
\hline $\begin{array}{l}\text { Sub- } \\
\text { kingdom } \\
\text { Super- } \\
\text { division }\end{array}$ & Tracheobionta & {$[9,10]$} \\
Division & Spermatophyta & \\
Class & Magnoliophyta & \\
Sub-class & Asteridae & \\
Order & Asterales & \\
Family & Asteraceae \\
Genus & Cotula \\
Species & Cinerea \\
Binomial & Cotula cinerea Del \\
name & & \\
Synonym & Brocchia cinerea Del \\
Vernacular & Gartoufa, Gartoufa & \\
names & beida, Chouihiya, 10,11,12] \\
& Chihia, Shihit El \\
& Ebel, Chiria, Robita \\
\hline
\end{tabular}

GENERAL BOTANICAL DESCRIPTION OF $c$. CINEREA

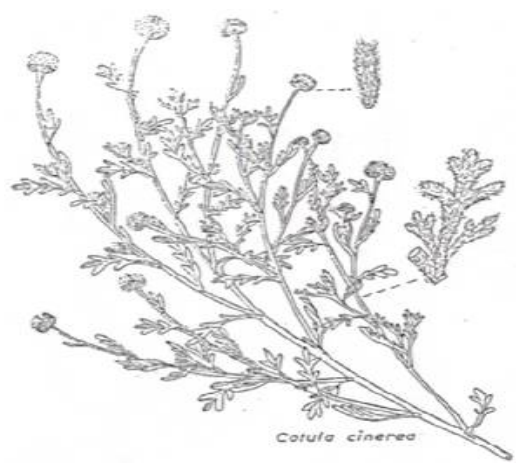

Figure 1: General morphology of $C$. cinerea [15]

Cotula cinerea is a small annual plant $(5$ to $15 \mathrm{~cm}$ in height) with a woolly appearance. It rarely reaches a height of $40 \mathrm{~cm}$ and is characterized by a whitish-green stem, diffuse or erect and covered with small dense hairs. The leaves are small, whitish-green in color and covered with small, dense hairs (Figure 1). In addition, the leaves are entire, thick and velvety, and are cut into three to seven teeth (or fingers), resembling slightly closed hands $[9,13,14]$. The flowers are yellow and grouped into discoid hemispherical heads ( 6 to $10 \mathrm{~mm}$ in diameter) at the tip of a short stem (Figure 2). The fruits of this species are small achenes, each of which does not exceed $5 \mathrm{~mm}$ in diameter [14].

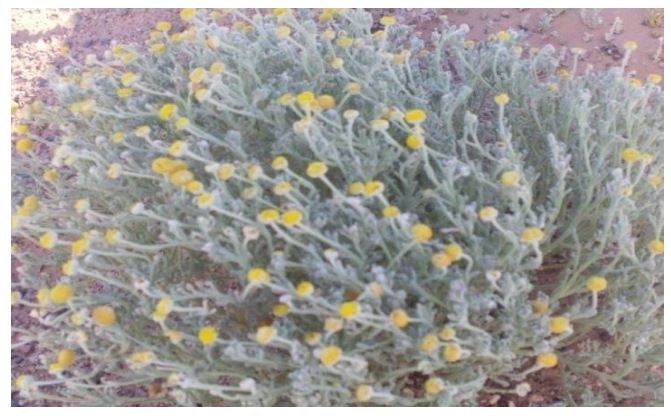

Figure 2: Photo of C. cinerea [16]

\section{GEOGRAPHICAL DISTRIBUTION OF $C$. CINEREA}

Cotula cinerea is a xerophytic plant; it thrives in desert conditions with an average annual rainfall of $100 \mathrm{~mm}$. The plant favors sand-loamy soils, and it is usually found on non-saline wadi beds on gravelly sandy soils [17]. Geographically, it is widely distributed in North Africa especially in the Saharan regions of Algeria and Morocco, Red Sea region, Sinai, Qattara Depression and Mali [18].

\section{TRADITIONAL USES OF C. CINEREA}

Traditionally, $C$. cinerea is extensively used to treat several diseases like colic, cough, diarrhea and digestive disorders. The plant is usually applied in the form of decoction, maceration, infusion and inhalation [19-21]. In traditional medical practice, it is used as an antiseptic, antipyretic, analgesic, and anti-inflammatory agent, and also for treating rheumatism [20,22]. The plant is also used in the treatment of fever and cough, and in the form of poultices against headaches and migraine [23]. In addition to its medicinal uses, the nomads use the plant as a tea additive for enhancement of the taste of tea. It is also used to filter goat butter, on account of its good preservative properties [24].

\section{PHYTOCHEMISTRY OF C. CINEREA}

Phytochemical screening of the aerial part of the $C$. cinerea showed the presence of saponins, essential oils, tannins, flavonoids, steroids and terpenoids $[16,25]$.

It has been reported that the total phenolic content of the chloroform extract of the aerial parts of $C$. cinerea was $485 \mathrm{mg}$ of gallic acid equivalents $/ 100 \mathrm{~g}$ dry weight, while the total flavonoid content was $281.4 \mathrm{mg}$ of 
quercetin/100g dry weight [24]. The plant sample used in that study was harvested in the region of Ouargla (Southeastern Algeria) during the flowering stage.

In another study on the flower parts of $C$. cinerea harvested in Adrar region, southern Algeria, Belyagoubi-Benhammou et al [26] obtained total phenolic content of $22.22 \pm 0.41 \mathrm{mg}$ gallic acid equivalents (determined by spectrometry); flavonoid yield of $3.93 \pm 0.06 \mathrm{mg}$ (determined colorimetrically) and proanthocyanid in level of $8.61 \pm 0.18 \mathrm{mg}$ catechin equivalents (determined by vanillin assay). The chemical compositions of the hydro-ethanol extract of the aerial parts of $C$. cinerea harvested at the flowering stage in Tougourt (southeastern Algeria) have been studied by Dendougui et al [27]. Eighteen compounds were identified in the study. These included a new germacranolide-type sesquiterpene lactone, and seventeen new flavonoids for the genus Cotula: (I) chrysospenolD, (II) chrysosplenetin, (III) oxyayanin-B, (IV) axillarin, (V) 3-methylquercetin, (VI) pedaletin, (VII) isokaempferid, (VIII) apigenin, (IX) luteolin, (X) 6-hydroxyluteolin, (XI) 3-glucosylisorhamnetin, (XII) 3-methyl-7-glucosylquercetin, (XIII) 7-O- $\beta$-D-glucosylapigenin, (XIV) 7-O- $\beta$-Dglucosylluteolin, (XV) 7-O- $\beta$-D-glucosyl-quercetin, (XVI) 7-O- $\beta-D-g l u c o s y l a x i l l a r i n$ and (XVII) $7-O-\beta-D$ - diglucosylluteolin. The structures of these compounds were established by spectral methods.

Six sesquiterpenes lactones (three germacranolids, two guaianolides, and one eudesmanolide) have isolated from the chloroform extract of the aerial parts of $C$. cinerea [24]. Their structures were established by spectral methods.
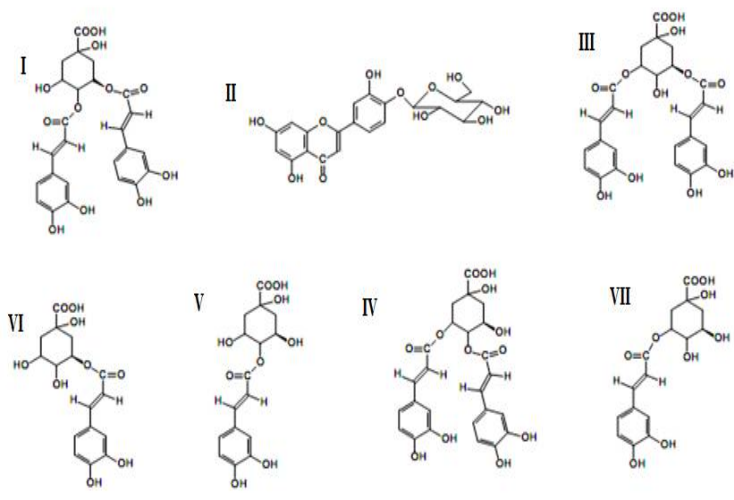

Figure 3: Structures of phenolic components of methanol extract of $C$. cinerea. I: 3, 4-dicaffeoylquinic acid; II: luteolin-4'-O-glucoside; III: 3, 5dicaffeoylquinic acid; IV, 4,5-dicaffeoylquinic acid; V: cryptochlorogenic acid; IV: chlorogenic acid; IIV: neochlorogenic acid
Studies on the methanol extracts of the aerial parts of $C$. cinerea harvested from Errachidia (Morocco) at the flowering stage revealed that the major phenolic compounds were luteolin-4'O-glucoside; 4,5-dicaffeoylquinic acid; 3,5dicaffeoylquinic acid; 3,4-dicaffeoylquinic acid; cryptochlorogenic acid; chlorogenic acid and neochlorogenic acid [24]. The structures of this compound were elucidated by HPLC-ESI-MS (Figure 3).

Table 2: Essential oil yield of $C$. cinerea from different geographical locations

\begin{tabular}{|c|c|c|c|}
\hline $\begin{array}{l}\text { Essential } \\
\text { oil yield } \\
\text { (v/w) }\end{array}$ & $\begin{array}{l}\text { Area of } \\
\text { harvest }\end{array}$ & $\begin{array}{l}\text { Harvest } \\
\text { season or } \\
\text { stage }\end{array}$ & Reference \\
\hline $0.080 \%$ & $\begin{array}{l}\text { Oued Souf } \\
\text { (South- } \\
\text { eastern } \\
\text { Algeria) }\end{array}$ & Flowering & [29] \\
\hline $0.391 \%$ & $\begin{array}{c}\text { Oued Souf } \\
\text { (South- } \\
\text { Eastern } \\
\text { Algeria) }\end{array}$ & Fruiting & [29] \\
\hline $0.75 \%$ & $\begin{array}{l}\text { Ouargla } \\
\text { (South- } \\
\text { Eastern } \\
\text { Algeria) }\end{array}$ & March & [24] \\
\hline $0.282 \%$ & $\begin{array}{l}\text { Bechar } \\
\text { (South- } \\
\text { Western } \\
\text { Algeria) }\end{array}$ & $\begin{array}{l}\text { February } \\
\text { and March }\end{array}$ & [30] \\
\hline $0.64 \%$ & $\begin{array}{l}\text { Smara } \\
\text { (Moroccan } \\
\text { Sahara) }\end{array}$ & March & [31] \\
\hline $0.87 \%$ & $\begin{array}{l}\text { Province } \\
\text { Zagora } \\
\text { (South of } \\
\text { Morocco) }\end{array}$ & $\begin{array}{l}\text { Flowering } \\
\text { phase }\end{array}$ & [32] \\
\hline $0.30 \%$ & $\begin{array}{l}\text { Desert } \\
\text { area } \\
\text { between } \\
\text { Cairo and } \\
\text { Ismailia } \\
\text { (Egypt) }\end{array}$ & Not stated & [33] \\
\hline
\end{tabular}

The essential oil of $C$. cinerea has also been subjected to many studies. The essential oil content of $C$. cinerea varies between 0.080 and $0.87 \%$ (Table 2). Samples of C. cinerea harvested in the region of Zagora (South Morocco) produced the highest oil yield. Many studies have been conducted to determine the effect of various factors on essential oil yield of C. cinerea. The oil essential yield is higher during the flowering period when compared to other periods [34], and the essential oil content increases with flowering [35]. The accumulation of essential oils during the full-flowering period has been related to the attraction of pollinators, and to the increase in antifungal defense system during this period [36]. The essential oil content 
also depends on precipitation, air movement, sunshine duration, relative humidity, and temperature [37]. Other factors that influence oil levels are the length of the day and altitude [38]; pedoclimatic conditions, as well as the ontogenic stage of the plant [39]. It has been reported that the yield of essential oil increases with accentuation of water deficit and decreases with increases in salt concentration [40]. In addition, essential oil content is influenced by the harvest stage, harvest time and mode of drying of the plant [41]. Generally, the yield of essential oils is influenced by intrinsic factors such as the condition of the plant, harvest period, genetic factors, as well as extrinsic issues such as the floral procession, insect pests, pollinators, climate and nature of the soil [29].

The physicochemical properties of essential oils from $C$. cinerea have also been investigated. It has been reported that the essential oil of $C$. cinerea is yellowish and viscous, and it is characterized by olfactory properties that resemble those of Artemisia [31]. Indeed, studies have indicated that at the fruiting stage, the essential oil of $C$. cinerea is characterized by a yellowish green color and viscous lingering odor, but at the flowering stage, the oil acquires a yellowish tinge [29]. In addition, the essential oil possesses a very agreeable aromatic odor. The physical properties of the essential oils have also been studied with respect to density, refractive index and rotatory power, resulting in values of $0.864,1.4610$ and $+115^{\circ}$, respectively [24]. Moreover, numerous studies have been conducted on the composition of essential oils of C. cinerea essential oil from different geographical regions [24,29-33,42]. The major chemical compounds present in $C$. cinerea essential oil from different regions are listed in Table 3 and Table 4. The relative amounts of each component were determined by GC-MS analysis.
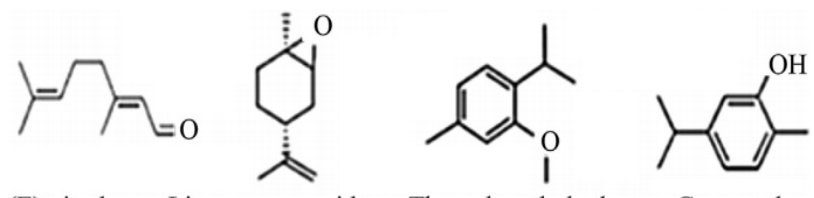

(E)-citra
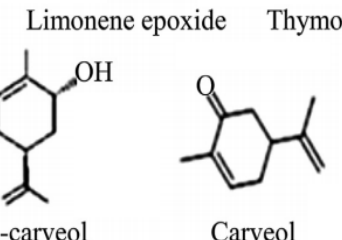

thyl ether

Carvacrol

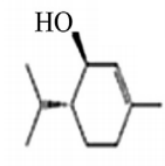

Trans-piperitol

Figure 4: Major compounds of $C$. cinerea essential oil from Bechar area (southwest Algeria) [30]
Table 3: Major chemical components essential oils from $C$. cinerea from different geographical locations

\begin{tabular}{lcc}
\hline $\begin{array}{l}\text { Geographic } \\
\text { al region }\end{array}$ & Major compound & Reference \\
\hline Ouargla & Thujone $(47.72 \%) ;$ & {$[24]$} \\
(South- & camphor $(10.54 \%) ;$ & \\
Eastern & santolinatriene $(8.00 \%) ;$ & \\
Algeria) & eucalyptol $(6.37 \%) ;$ & \\
& acetate $(4.17 \%)$, & \\
& terpinen-4-ol $(2.77 \%)$. &
\end{tabular}

Oued Souf

(South-

Eastern

Algeria)

3-Carène $(30.99 \%)$;
thujone $(21.73 \%)$;

[29a]

santolina triene

(18.58\%); camphor

(6.21\%); eucalyptol $(2.79 \%) ; 7^{\prime}$

Oxaspiro[cyclopropane-

1,4'tricyclo[3.3.1.0 $(6,8)]$

nonan-2'-one] (2.98\%);

terpinen-4-ol (3.64\%);

o-menth-1-en-8-ol

(3.01\%); trans-

pinocarveol (1.28\%).

Oued Souf

(South-

Thujone (28.78\%); 3-

carène $(15.90 \%)$;

Eastern

Algeria)

eucalyptol (15.13\%);

santolina triene

(13.38\%); camphor

(7.49\%), M-cymene

(3.34\%); 7'-oxaspiro

[cyclopropane-1,4'-

tricyclo[3.3.1.0 $(6,8)]$

nonan-2'-one] (3.31\%);

4(10)-thujen-3-ol,

stereoisomer (1.47\%);

terpinen-4-ol (4.26\%)

and $p$-menth-1-en-8-ol

(1.65\%); 3-thujanone

(0.99\%); isoborneol

$(0.61 \%)$; pinene

$(0.47 \%)$; camphene

(0.37); p-cymen-8-ol

$$
\text { (0.30); }
$$

$1,2,2,3-$

tetramethylcyclopent-3enol $(0.24 \%)$;

origanene $(0.23 \%)$;

beta-phellandrene $(0.21 \%)$.

[29b]

(Southwest Algeria) harvested at the fruiting period.
(E)-citral (24.01\%); cislimonene epoxide (18.26\%); thymol methylether (15.04\%); carvacrol (15.03\%);

trans-carveol (13.79\%);

carvone $(3.06 \%)$; transpiperitol (2.54\%).

[30]

Trop J Pharm Res, February 2018; 17(2): 368 
Table 4: Major chemical compounds in the essential oil of $C$. cinerea from different geographical locations

\begin{tabular}{|c|c|c|}
\hline $\begin{array}{l}\text { Geographical } \\
\text { region }\end{array}$ & $\begin{array}{c}\text { Major } \\
\text { compound }\end{array}$ & Reference \\
\hline $\begin{array}{l}\text { Smara } \\
\text { (Moroccan } \\
\text { Sahara) }\end{array}$ & $\begin{array}{c}\text { Iso-3thujanol } \\
\text { (47.38\%); } \\
\text { Santolina } \\
\text { triene } \\
(11.67 \%) ; \\
\text { camphor } \\
\text { (10.95\%); } \\
\text { santolina } \\
\text { alcohol } \\
\text { (7.68\%); } \\
\text { borneol } \\
\text { (5.49\%); neo- } \\
\text { iso-3-thujanol } \\
(3.74 \%) ; \text { ß- } \\
\text { pinene } \\
\text { (2.98\%). }\end{array}$ & [31] \\
\hline $\begin{array}{l}\text { Province } \\
\text { Zagora } \\
\text { (Morocco) }\end{array}$ & $\begin{array}{c}\text { Trans-thujone } \\
\text { (41.4\%); cis- } \\
\text { verbenyl } \\
\text { acetate } \\
(24.7 \%) ; 1,8- \\
\text { cineole } \\
(8.2 \%) ; \\
\text { santolinatriene } \\
(7.2 \%) ; \\
\text { camphor } \\
(5.5 \%) .\end{array}$ & [32] \\
\hline $\begin{array}{l}\text { Desert area } \\
\text { between } \\
\text { Cairo and } \\
\text { Ismailia } \\
\text { (Egypt) }\end{array}$ & $\begin{array}{c}\text { Camphor } \\
\text { (50\%); alpha } \\
\text { and beta- } \\
\text { thujone (15\%). }\end{array}$ & [33] \\
\hline
\end{tabular}

Results from analysis and identification of components showed that the main constituents of essential oil from the aerial parts of $C$. cinerea vary from region to region. The structures of some major compounds are given in Figure 4. The qualitative and quantitative differences in the chemical compositions of essential oil could be attributed to several factors. The chemical components of essential oils are influenced by several intrinsic and extrinsic factors [42].

Qualitative variation in oil composition is thought to be influenced by intrinsic genetic factors, whereas quantitative variation is influenced by extrinsic factors [43]. It has been revealed that the composition of the essential oils is influenced by a multiplicity of factors such as plant ontogeny, site of oil production, photosynthesis, plant growth regulators, plant density, soil salinity, harvesting stage, seasonal variations and climatic conditions [44].
PHARMACOLOGICAL ACTIVITIES OF $C$. CINEREA

Several pharmacological activities and medicinal applications of $C$. cinerea are widely known. A summary of the biological studies on this plant is presented below.

\section{Antibacterial activity of $C$. cinerea}

The antibacterial activity of $C$. cinerea extracts has been reported in a number of studies. Many researchers have investigated the antibacterial activity of essential oils from C. cinerea and reported that it possesses broad-spectrum antibacterial activity when tested by direct contact with pathogenic bacteria such as Enterococcus faecalis, Salmonnella heidelberg, Staphyloccocus aureus, Klebsiella pneumoniae, Echerichia coli, Pseudomonas aeruginosa, Enterobacter cloacae, Enterococcus faecium, Morganella morganii, Citrobacter freundii, Proteus vulgaris, Acinetobacter baumannii, Bacillus subtilis and Micrococcus luteus $[29,31,45]$. Some studies reported a relationship between the chemical structures of the major compounds in the essential oils of $C$. cinerea and its antibacterial activity. It has been reported that the ethylacetate and $n$-butanol extracts of the aerial parts of $C$. cinerea aerial part showed antibacterial activity against Pseudomonas fluorescens, Pseudomonas savastanoui, Bacillus sp., Bacillus brevis and Bacillus sphaericus [46], while the ethyl ether extract produced no antimicrobial activity against these bacterial strains. In another study, $70 \%$ ethanol, $n$-butanol, ethyl acetate and petroleum ether extracts of the aerial part of $C$. cinerea elicited antibacterial activities against Staphylococcus aureus, Klebsiella pneumoniae, Pseudomonas aeruginosa and Escherichia coli [47].

\section{Antifungal activity of $C$. cinerea}

The essential oils of $C$. cinerea when tested by direct contact, suppressed the growth of Aspergillus niger, Penicillium digitatum, Penicillium expansum, Gloeophyl lumtrabeum, Coniophora puteana, Poria placenta and Coriolus versicolor [31]. In another antifungal study, Candida albicans was inhibited by $70 \%$ ethanol, $n$-butanol, ethyl acetate and petroleum ether extracts of $C$. cinerea [47]. Flavonoid and cell wall polysaccharide (hemicellulose and methylated pectins) extracts of the leaves and flowers of $C$. cinerea inhibited mycelia growth, germination and sporulation of the pathogenic fungi Fusarium oxysporum f.sp. albedinis [16]. In the same study, flavonoid extracts reduced the relative virulence, and inhibited the cellulase 
activity of the fungi. However, the synthesis of Fusarium oxysporum toxins was not affected.

It is important to point out that the antimicrobial effects of the major identified constituents of the essential oils from $C$. cinerea were not investigated in previous studies.

Many studies have demonstrated that the inhibitory effect of an essential oil results from a complex interactions between its different constituents: these interactions may produce synergistic, additive or antagonistic effects even with components present at low concentrations $[48,49]$.

\section{Antioxidant property of $C$. cinerea}

The antioxidant properties of methanol extract of C. cinerea collected in Adrar region, Southern Algeria have been investigated through 1, 1diphenyl-2-picrylhydrazyl (DPPH) radical scavenging, hydroxyl radical scavenging, reducing power and total antioxidant capacity [26]. The results showed that the plant exhibited strong antioxidant activity, with $\mathrm{EC}_{50}$ of 462.19 $\mathrm{mg}$ antioxidant/g DPPH (DPPH radical scavenging assay); $E_{50}$ of $0.66 \pm 0.12 \mathrm{mg} / \mathrm{ml}$ (hydroxyl radical scavenging assay); $\mathrm{IC}_{50}$ of $1.174 \pm 0.05 \mathrm{mg} / \mathrm{ml}$ (reducing power assay), and $17.190 \pm 1.273 \mathrm{mg}$ of ascorbic acid equivalents $/ \mathrm{g}$ dry weight (total antioxidant capacity).

In another study, the antioxidant activity of the essential oil of $C$. cinerea collected from South Morocco was stablished using DPPH free radical-scavenging, B-carotene/linoleic acid bleaching, and ABTS free radical scavenging assays [50].

\section{In vivo anti-diarrheal effect of $C$. cinerea}

Diarrhea is one of the most common causes of morbidity and mortality in many countries. In third world countries, it is responsible for the death of millions of people each year. Children are more susceptible to this disease which is considered as the second leading causes to death of children less than five years old [51]. Traditionally, C. cinerea plays an important role in the treatment of diarrhea and gastrointestinal disorders. However, there is limited scientific evidence supporting the use of this plant as an antidiarrheal agent. Aqueous extract of the aerial-part of $C$. cinerea (collected during the flowering period from the Errachidia Sahara region in Morocco) was tested for antidiarrheal activity using castor oil-induced diarrhea rat model, and also for gastrointestinal transit in mice [52]. The results showed that oral administration of the aqueous extract at doses of 50,100 and $250 \mathrm{mg} / \mathrm{kg}$ significantly reduced fecal output of the rats by $30.17,56.79$ and 100 $\%$, respectively, and increased the time taken to reach $100 \mathrm{mg} / \mathrm{kg}$, while the reduction in fecal output by loperamide (10 mg/kg), was $100 \%$ when compared with the untreated group. The results of gastrointestinal motility test revealed that small intestinal motility of charcoal meal in mice was significantly inhibited $(48.57 \%)$ at 250 $\mathrm{mg} / \mathrm{kg}$ of the aqueous extract when compared to the control, while the inhibition produced by loperamide $(10 \mathrm{mg} / \mathrm{kg})$ was $78.5 \%$. The authors suggested that the antidiarrheal effect of the aqueous extract was probably exerted through an anti-secretory mechanism and/or antispasmodic effect which reduced intestinal contractions thereby allowing a greater time for absorption of water.

These results lend some credence to the widespread traditional use of $C$. cinerea as an antidiarrheal agent by the Northern Africa population.

\section{Herbicidal effect of $C$. cinerea}

The herbicidal activity of $C$. cinerea against Melilotus indicus (potential seed crop contaminant causing great loss in crop productivity) has been investigated [25]. The results showed that percentage germination, plumule and radicle lengths, and seedling dry weight were significantly inhibited by applying different concentrations of $C$. cinerea shoot extract. The authors also evaluated the effect of $C$. cinerea shoot powder mixed with different levels of sandy loam soils (on weight-to-weight basis), on some growth parameters, total available carbohydrates and total protein contents of $M$. indicus. It was revealed that the shoot and root lengths of $M$. indicus were significantly affected by different levels of $C$. cinerea shoot powder. The leaf area index and the total photosynthetic pigments were significant reduced in the recipient species by treatment with different levels $C$. cinerea shoot powder. On the other hand, carotenoid content was significantly increased with increase in C. cinerea shoot powder level. Total available carbohydrates and total protein contents of the recipient species were significantly decreased with increase in the amount of $C$. cinerea shoot powder.

Based on these results, there is a possibility of using the allelopathic potential of $C$. cinerea directly or in structure leads, for the discovery and development of environmental herbicides. 


\section{Analgesic properties of $C$. cinerea}

Studies have been carried out on the possible analgesic effects of different extracts of $C$. cinerea (collected from Zagora, Morocco) [46]. Ethyl ether, ethyl acetate or n-butanol, and the reference drug acetyl salicylic acid, were orally administered to mice at a dose of $100 \mathrm{mg} / \mathrm{kg}$, while mice in the control group received only water. After $1 \mathrm{~h}, 0.6 \%$ acetic acid solution was injected intraperitoneally to the mice at a dose of $15 \mathrm{~mL} / \mathrm{kg}$. Nociception was evaluated $15 \mathrm{~min}$ after acetic acid injection by counting the number of abdominal constrictions for a period of $5 \mathrm{~min}$. The results showed moderate analgesic effects of the ethyl acetate and n-butanol extracts, with constriction inhibitions of 50 and $40.21 \%$, respectively. In contrast, the constriction inhibition produced by the ethyl ether extract $(62.49 \%)$ was close to that of the reference drug (73.9\%).

Based on these results, it can be reasonably suggested that the isolation of the active compound(s) from these extracts may yield novel analgesic agents. Moreover, these findings justify the folkloric use of the plant for treating pain and inflammatory diseases.

\section{Nutritional value of $C$. cinerea}

Knowledge of dromedary-desert rangelands relationships is an essential element in the management and eco-development of the northwest Algerian Sahara which constitutes the habitat of various plants grazed by this animal. The dromedary is the only breeding species able to use these Saharan plants, making them valuable for the production of milk and meat, which constitute an important food resource for indigenous peoples [53]. The nutritional value (energy and nitrogenous values) of $C$. cinerea of the North Algerian Sahara have been evaluated [53]. The nutritional value assessment (based on chemical composition of this species) showed low values of fodder unit milk and of fodder unit meat $(0.31$ and 0.27 , respectively). Nitrogenous value assessment of $C$. cinerea showed that the values of digestible protein in the small intestine limited by nitrogen (PDIN) and digestible protein in the small intestine limited by energy (PDIE) were $34.01 \pm 1.14 \mathrm{~g}$ and $27.86 \pm 2.72 \mathrm{~g}$, respectively.

\section{CONCLUDING REMARKS}

This review is aimed at providing comprehensive and up-to-date information on research on the traditional uses, phytochemistry and biological activities of $C$. cinerea. The reported pharmacological properties of this species confirm its traditional uses. The plant possesses antibacterial, antifungal, antioxidant, herbicidal, anti-diarrheal and analgesic properties. Most of the therapeutic effects may be due to the presence of various phytoconstituents such as saponins, essential oil, tannins, flavonoids, steroids, and terpenoids. However, more investigations are needed to elucidate the exact mechanism(s) involved, as well as the nature of the bioactive components.

\section{DECLARATIONS}

\section{Acknowledgement}

The author thanks all the people who supported the writing of this paper.

\section{Conflict of Interest}

No conflict of interest associated with this work.

\section{Contribution of Authors}

The author declares that this work was done by the author named in this article and all liabilities pertaining to claims relating to the content of this article will be borne by him.

\section{REFERENCES}

1. Zulkhairi HA, A. Khairunnuur $F$, Hafipah MRN, Azrina A, Rasadah M A, Kamilah KAK, Zamree MS, Shahidan MA. An aqueous extract of Citrus mitis possesses antioxidative properties and improves plasma lipid profiles in rat induced with high cholesterol diet. J Med Plants Res 2010; 4(1): 49-57.

2. Kubmarawa D, Ajoku GA, Enwerem NM, Okorie DA. Preliminary phytochemical and antimicrobial screening of 50 medicinal plants from Nigeria. Afr $J$ Biotechnol 2007; 6: 1690-1696.

3. Pourmohammad A. Application of molecular markers in medicinal plant studies. Acta Univ Sap Agr Env 2013; 5: 80-90.

4. Cragg GM, Newman DJ, Snader KM. Natural Products in Drug Discovery and Development. J Nat Prod 1997; 60(1): 52-60.

5. Saadabi AMA, Sehemi AGAL, AL-Zailaie KA. In vitro antimicrobial activity of some Saudi Arabian plants used in folkloric medicine. Int J Bot 2006; 2: 201-204.

6. Agrawal B, Das S, Pandey A. Boerhaavia diffusa Linn: A review on its phytochemical and pharmacological profile. Asian J Applied Sci 2011; 4: 663-684.

7. Luczaj L, Szymanski WM. Wild vascular plants gathered for consumption in the Polish countryside: a review. $J$ Ethnobiol Ethnomed 2007; 3: 17. 
8. Alves RR, Rosa IM. Biodiversity, traditional medicine and public health: where do they meet? J Ethnobiol Ethnomed 2007; 3: 14.

9. Quezel P, Santa S. Nouvelle flore de l'Algérie et des régions désertiques méridionales. Tome II, Ed. CNRS, Paris; $1963.1170 p$.

10. Dupont F, Guignard JL. Abrégés botanique systématique moléculaire. 13 édition révisée, Masson; 2004. 283 p.

11. Maiza K, Brac DLP, Hammiche V. Pharmacopée traditionnelle saharienne: Sahara septentrional. in: Actes du 2ème Colloque Européen d'Ethnopharmacologie et 11ème Conférence Internationale d'Ethnomédecine. - Heidelberg; 1993. $p$. 169-171.

12. Halis Y. Plant Encyclopedia in area Oued Souf: desert plants common in the Big East race. El Oued, Algeria: El Walid 2007; 154-155.

13. Ozenda P. [Flora of the Sahara]. Paris: French National Center for Scientific Research. French; 1983. 270 p.

14. Benhouhou S. Cotula cinerea. In: A guide to Medicinal Plants in North Africa. Union Internationale pour la conservation de la nature et de ses ressources; 2005 .p. 99-100.

15. Ozenda P. Flore du Sahara. CNRS. Paris; 1967. 270 p.

16. Mebarki L. Search of biological activity of plant molecules for controling Fusarium oxysporum f. sp. albedinis. Phd thesis, USTOMB, Oran, Algeria; 2016. $191 p$.

17. Boulos, L. Medicinal Plants of North Africa. Reference Publication Algonac, Michigan. USA; 1983. 286 p.

18. Ozenda P. Flore et végétation du Sahara. Ed. CNRS, Paris; 1991. $662 p$.

19. Bellakhdar J. La pharmacopée marocaine traditionnelle. Médecine arabe ancienne et savoirs populaires. Ibis Press - Edition Le Fennec; 1997. $764 p$.

20. Beloued A. Les plantes médicinales d'Algérie. Ed. Office des publications universitaires (OPU), Algiers; 2005. $284 p$.

21. Djellouli M, Moussaoui A, Benmehdi $H$, Ziane L, Belabbes $A$, Badraoui $M$, et al. Ethnopharmacological study and phytochemical screening of three plants (Asteraceae family) from the region of south west Algeria. Asian J Nat Appl Sci 2013; 2(2): 59-65.

22. Hammiche V, Maiza K. Traditional medicine in Central Sahara: Pharmacopoeia of Tassili N'ajjer. J Ethnopharmacol 2006; 105: 358-367.

23. Atef $C$, Chefrour $A$. Seasonal biometric and dynamic monitoring of the Shihia plant Cotula cinerea Del (1831) and its accompanying plants in the Saharan region Oued-Souf (south-east of Algeria). Int J SciRes 2014; 3(7): 826-833.

24. Bouziane M, Badjah-Hadj-Ahmed Y, Hadj-Mahammed M. Chemical Composition of the Essential oil of Brocchia cinerea Grown in South Eastern of Algeria. Asian J Chem 2013; 25 (7): 3917-3921.

25. Mabroka M, Hemada, Salama M, El-Darier. Management of A Noxious Weed; Melilotus indicus L.via Allelopathy of Cotula cinerea Del. Int J Adv Res 2015; 3(3): 553-56.
26. Belyagoubi-Benhammou N, Belyagoubi L, Atik Bekkara $F$. Phenolic contents and antioxidant activities in vitro of some selected Algerian plants. J Med Plants Res 2014; 8(40): 1198-1207.

27. Dendougui $H$, Seghir $S$, Jay $M$, Benayache $F$, Benayache S. Flavonoids From Cotula Cinerea Del. Int J Med Arom Plants 2012; 2(4) : 589-595.

28. Khallouki F, Sellam K, Koyun R, Ricarte I, Alem C, Elrhaffari L, Owen RW. Phytoconstituents and in vitro Evaluation of Antioxidant Capacities of Cotula Cinerea (Morocco) Methanol Extracts. Rec Nat Prod 2015; 9(4): 572-575.

29. Atef C, Mayache B, Maazi MC, Hadef $Y$, Chefrour A. Chemical composition and antimicrobial activity of essential oils in Xerophytic plant Cotula cinerea Del (Asteraceae) during two stages of development: flowering and fruiting. J Appl Pharm Sci 2015; 5 (03): 029-034.

30. Djellouli M, Benmehdi H, Mammeri S, Moussaoui A, Ziane L, Hamidi $N$. Chemical Constituents in the Essential Oil of the Endemic Plant Cotula Cinerea (Del.) from the South West of Algeria. Asian Pac J Trop Biomed 2015; 5(10): 870-873.

31. Ekhilil B, Mohamed G, Badr S, Brahim AM, Rachid R, et al. Chemical Quality, Antibacterial and Antifungal activities of Cotula Cinerea essential oil from South Morocco. Environ Sci Ind J 2016; 12(5): 209-216.

32. El Bouzidi L, Abbad A, Fattarsi K, Hassani L, Leach D, Markouk M, Legendre L, Bekkouche K. Chemical composition and Anticandidal properties of the essential oil isolated from aerial parts of Cotula Cinerea: a rare and threatened medicinal plant in Morocco. Nat Prod Commun 2011; 6(10): 1491-1494.

33. Fournier G, Baghdadi H, Ahmed S, Paris M. Contribution to the study of Cotula Cinerea essential oil. Planta Med 1989; 55(6): 580-580.

34. Toncer $O$, Karaman S, Diraz E. An annual variation in essential oil composition of Origanum syriacum from Southeast Anatolia of Turkey. J Med Plants Res 2010; 4(11): 1059-1064.

35. Putievsky E, Ravid U, Dudai N. Phenological and seasonal influences on essential oil of a cultivated clone of Origanum vulgare L . J Sci Food Agric 1988; 43(3): 225-228.

36. Sellami IH, Maamouri E, Chahed T, Wannes WA, Kchouk ME, Marzouk B. Effect of growth stage on the content and composition of the essential oil and phenolic fraction of sweet marjoram (Origanum majorana L.), Ind Crops Prod 2009; 30: 395-402.

37. Safaii L, Ashoorabadi ES, Emami SD, Afiuni D. The effect of harvesting stages on quantitative and qualitative characters of essential oil and phenolic yield composition in two thyme species (Thymus daenensis Celak andT. vulgaris L.) in Iran. Int J Agri Crop Sci 2014; 7 (13): 1346-1351.

38. Golparvar AR. Determination of the best harvesting times to obtain maximum dry herbage, essential oil and 
Thymol yield in garden Thyme (Thymus vulgaris L.). Int $J$ Life Sci Med Res 2011; 1(1): 1-4.

39. Marotti M, Dellacecca V, Piccaglia R, Giovanelli E. Effect of harvesting stage on the yield and essential oil composition of peppermint (Mentha x piperita L.). Acta. Hortic. (ISHS) 1993; 344: 370-379.

40. Ozturk A, Unlukara A, Ipek A, Gurbuz B. Effects of salt stress and water deficet on plant growth and essential oil content of Lemon Balm (Melissa officinalis L.). Pak J Bot 2004; 36(4): 787-792

41. Filiz A. Effects of harvesting stages, harvesting hours and drying methods on essential oil content of lemon balm grown in Eastern Mediterranean. J Botany 2005; 1: 138142.

42. Janina MS. Melissa officinalis. Int J Aromather 2003; 10 : 132-139.

43. Franz C. Genetics. In Hay, RKM, Waterman PG. editors. Volatile Oil Crops. Longman Scientific et Technical, Essex; 1993. p. 63-96.

44. Sangwan NS, Farooqi AHA, Shabih F, Sangwan RS. Regulation of essential oil production in plants. Plant Growth Regul 2001; 34: 3-21.

45. Abdenbi A, Abdelwahed DE, Touati B, Bouaaza M. Screening phytochimique et activite antibacterienne de l'huile essentielle de Cotula Cinerea (Gartoufa) dans la region de bechar. Intl J Res Eng Tec 2014; 2(2): 49-54.

46. Markouk M, Redwane A, Lazrek HB, Jana M, Benjama A. Antibacterial activity of Cotula cinerea extracts. Fitoterapia 1999; 70: 314-316.
47. Bensizerara D, Menasria $T$, Melouka M, Cheriet $L$, Chenchouni $H$. Antimicrobial activity of xerophytic plant (Cotula cinerea Delile, 1831) extracts against some pathogenic bacteria and fungi. Asian Pac J Trop Biomed 2012; 1-5.

48. Zakarya D, Fkih-Tetouani S, Hajji F. Chemical composition Antimicrobial activity relationship of Eucalyptus essential oils. Plant Méd Phytothér 1993; 26 : 331-339.

49. Xianfei X, Xiaoqiang C, Shunying Z, Guolin Z. Chemical composition and antimicrobial activity of essential oils of Chaenomeles speciosa from China. Food Chem 2007; 100 (4): 1312-1315.

50. Kasrati A, Jamali CA, Bekkouche K, Wohlmuth $H$, Leach $D$, Abbad A. Comparative evaluation of antioxidant and insecticidal properties of essential oils from five Moroccan aromatic herbs. J Food Sci Tech 2015; 52(4): 2312-2319.

51. Saralaya MG, Patel P, Patel M, Roy SP, Patel AN. Antidiarrheal activity of methanolic extract of Moringa oleifera Lam roots in experimental animal models. Int $J$ Pharm Res 2010; 2(2):35-39.

52. Beyi L, Aziz M, Makrane H, Karim A, Alem C, Amrani S, Legssyer A, Mekhfi H. Anti-Diarrheal Effect of Cotula Cinerea Del. Aqueous Extract on Rats and Mice. Res J Pharm Biol Chem Sci 2015; 6(6): 219-224.

53. Bouallala M, Chehma A, Hamel F. Evaluation de la valeur nutritive de quelques plantes herbacées broutées par le dromadaire dans le sahara Nord-occidental algérien. Lebanese Sci J 2013; 14(1): 33-39. 